14

\title{
Методика микрофокусной рентгенографии для выявления скрытой дефектности семян древесных лесных пород и других видов сосудистых растений
}

\author{
(C) М.В. Архипов, ${ }^{1,5}$ Н.С. Прияткин, ${ }^{1}$ Л.П. Гусакова, ${ }^{1}$ А.В. Карамышева, ${ }^{2}$ Л.П. Трофимук, ${ }^{3}$ Н.Н. Потрахов, ${ }^{4}$ \\ В.Б. Бессонов, ${ }^{4}$ П.А. Щукина ${ }^{1}$
}

${ }^{1}$ Агрофизический научно-исследовательский институт, 195220 Санкт-Петербург, Россия

${ }^{2}$ Ботанический институт им. В.Л. Комарова РАН, 197376 Санкт-Петербург, Россия

${ }^{3}$ Научно-опытная станция „Отрадное“ Ботанического института им. В.Л. Комарова РАН, 188750 пос. Плодовое, Приозерский район, Ленинградская обл., Россия

${ }^{4}$ Санкт-Петербургский государственный электротехнический университет им. В.И. Ульянова (Ленина), 197376 Санкт-Петербург, Россия

${ }^{5}$ Северо-Западный центр междисциплинарных проблем продовольственного обеспечения, 196608 Пушкин, Санкт-Петербург, Россия e-mail: prini@mail.ru

Поступило в Редакцию 30 апреля 2019 г. В окончательной редакции 30 апреля 2019 г. Принято к публикации 29 июня 2019 г.

Приведены характеристики современных аппаратных решений, используемых для получения цифровых рентгеновских изображений семян. Описаны основные способы визуализации и приемы анализа цифровых рентгеновских изображений семян. Выявлены и проанализированы скрытые дефекты образцов семян исследуемых древесных лесных пород: сосны кедровой сибирской (Pinus sibirica DuTour) и сосны кедровой корейской (P. Koraiensis Siebold \& Zucc.), кукурузы сахарной (Zeamays L.), а также огурца посевного (Cucumis sativum L.) и перца овощного (Capsicum annuum L.) методом микрофокусной рентгенографии в сочетании с автоматическим анализом цифровых рентгеновских изображений. Показано, что пустозернистые и частично полнозернистые семена имеют пониженные значения показателя „Средняя яркость“ рентгенограмм. Проведена сравнительная оценка рентгеновских показателей и всхожести проростков как интегральных показателей для оценки биологической полноценности семян.

Ключевые слова: микрофокусная рентгенография семян, анализ изображений семян, посевные качества семян, семена древесных лесных пород, семена сельскохозяйственных культур.

DOI: 10.21883/JTF.2020.02.48830.178-19

\section{Введение}

Рентгеновский метод оценки качества семян подробно описан как в отечественной литературе $[1,2]$, так и за рубежом [3-6]. С 1976 г. метод включен в международные и отечественные стандарты, в первую очередь по оценке зараженности и поврежденности зерна вредителями. С его помощью можно обнаруживать различные структурные дефекты семян, такие как трещиноватость, энзимомикозное истощение (ЭМИС), внутреннее прорастание, скрытая заселенность вредителями, повреждение клопом „вредная черепашка“, механические травмы и дефектность зародыша, пустозернистость. Методика может использоваться для семян, различных по плотности и размерам. Simak и Gustafsson в 1953 г. на базе метода рентгенографии разработали методику изучения внутреннего строения семян интродуцентов древесных пород с целью анализа полиэмбрионии зародышей, их индивидуальной и географической изменчивости, а также выбраковки пустых и поврежденных семян [7]. Kamra в 1976 г. показана эффективность рентгенографии для выявления пустозернистости, скрытой поврежденности насекомыми, механических повреждений и других дефектов при исследовании семян тропических древесных лесных пород [8].

С появлением современных технических и программных средств в мировом семеноведении активно используются технологии компьютерного анализа изображений семян $[9,10]$, в том числе денситометрического анализа цифровых рентгеновских изображений $[5,11]$. Например, с помощью автоматического анализа цифровых рентгеновских изображений семян древесных лесных пород стало возможным отделять жизнеспособные и нежизнеспособные семена хвойных пород на основании данных оптической плотности внутренних структур семени, а также определять их анатомическую зрелость [12].

Показательным представляется проведение рентгеновского анализа семян, за которым следует стандартный тест на энергию прорастания и всхожесть (ГОСТ 12038$84)$, тем более что после съемки семян в мягколучевом рентгене они полностью сохраняют свою жизнеспособность $[13,14]$. Ф.Б. Мусаевым с соавторами (2016) 


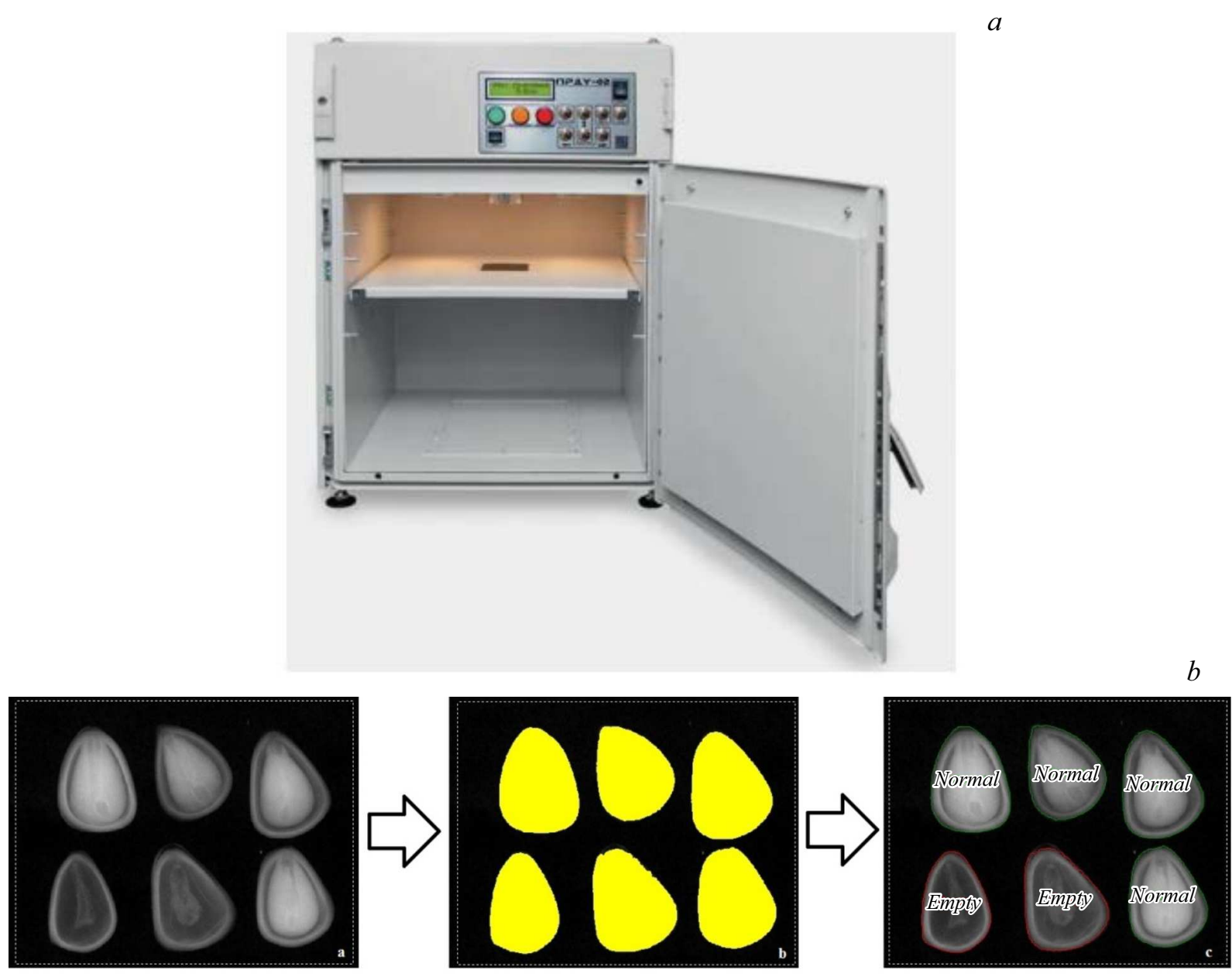

Рис. 1. Рентгенодиагностическая установка ПРДУ-02 (a) с универсальным программным обеспечением ARGUS-BIO (b) для анализа цифровых рентгеновских изображений семян.

детально изучена взаимосвязь ростовых показателей семян овощных культур и их скрытой дефектности, оцениваемой по рентгеновским снимкам [2]. T.A. AlTurki (2017) при сопряженном исследовании всхожести и рентгеновских изображений семян нескольких видов древесных лесных пород Саудовской Аравии показана высокая эффективность рентгенографии при выявлении недоразвитости эндосперма [15].

В Агрофизическом институте ведется многолетняя работа по исследованию скрытой дефектности семян различных видов сельскохозяйственных растений. Получены результаты как при использовании „пленочной“ [16] технологии, так и микрофокусной рентгенографии в цифровом исполнении [1]. В последние годы показана информативность автоматического анализа цифровых рентгеновских изображений образцов зерновок пшеницы и ячменя, полученных в результате диэлектрической сепарации исследуемых партий зерна [17], семян кукурузы с дефектами биогенного происхождения [18], желудей дуба черешчатого для обнаружения микротрещин и энзимомикозного истощения [19].
Целью настоящей работы было рассмотрение методики микрофокусной рентгенографии и приемов автоматического анализа цифровых рентгеновских изображений для выявления скрытой дефектности семян древесных лесных пород и других видов сосудистых растений.

Основные задачи настоящей работы включают в себя рассмотрение следующих вопросов:

- характеристики современных аппаратных решений, используемых для получения цифровых рентгеновских и компьютерных микротомографических изображений семян;

- обсуждение основных способов визуализации и приемов анализа цифровых рентгеновских изображений семян;

- сравнительная оценка рентгеновских показателей и всхожести проростков как интегральных показателей для оценки биологической полноценности семян.

\section{Основная часть}

Объектами исследований служили семена сосны кедровой сибирской (Pinus sibirica DuTour) и сосны кед- 


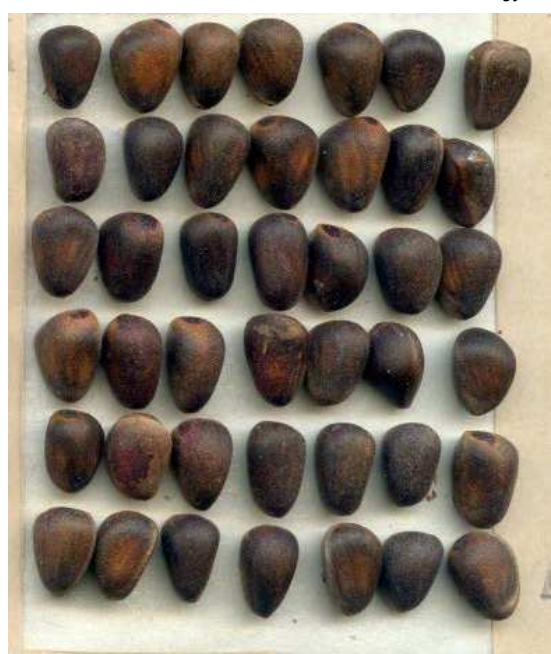

d

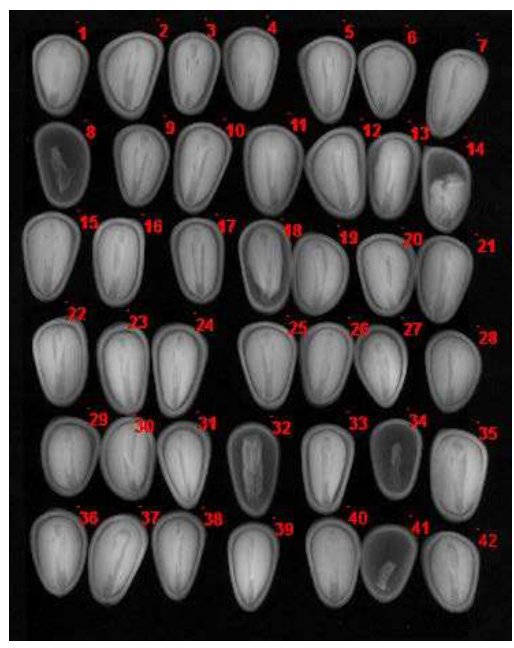

$b$

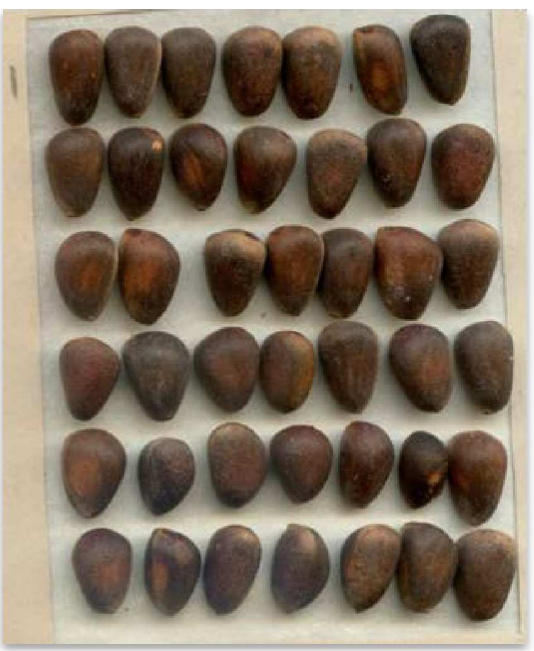

C

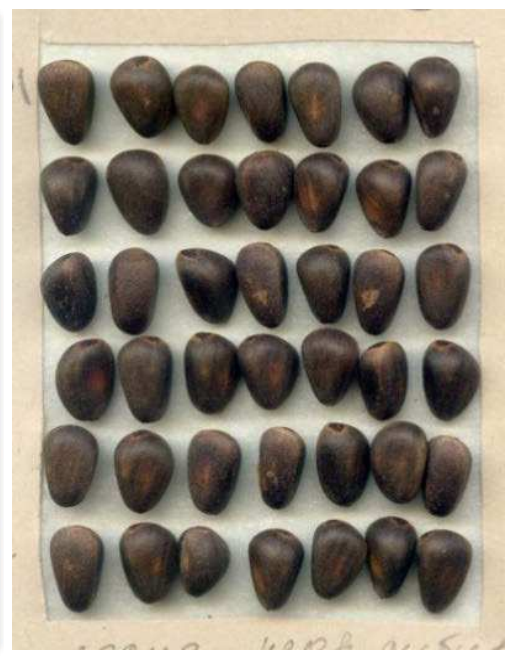

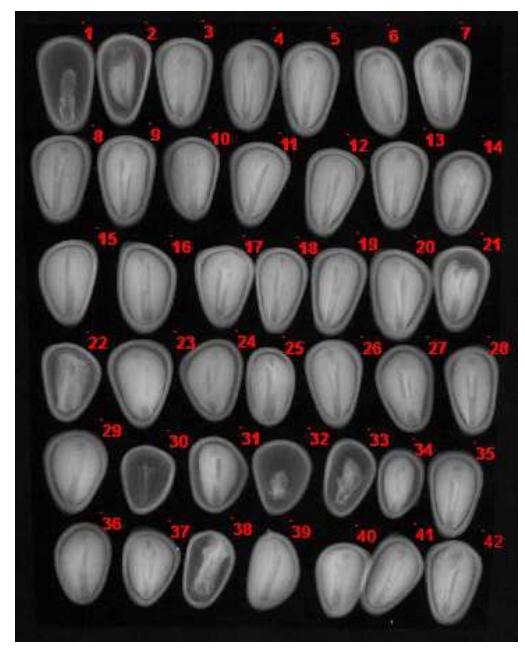

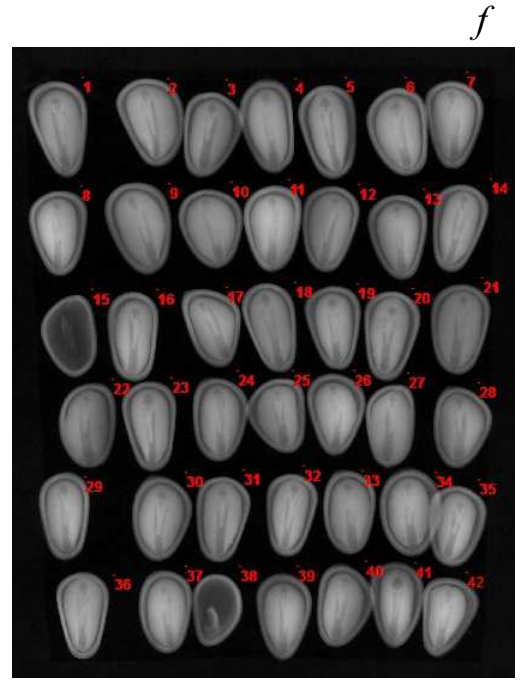

Рис. 2. Цифровые сканированные $(a, b)$ и рентгеновские $(c, d)$ изображения Pinussibirica, происхождение - Новосибирск $(a, b, d, e)$ и Республика Тыва $(c, f)$.

ровой корейской (P. Koraiensis Siebold \& Zucc.) из Новосибирска и Республики Тыва, кукурузы сахарной (Zea mays L.), огурца посевного (Cucumis sativus L.) и перца овощного (Capsicum annuum L.).

Для расположения семян в нужной для рентгенсъемки позиции были использованы специальные карточки, изготавливаемые из тонкой клеящейся ленты на бумажной или целлофановой основе. Вследствие малых размеров и низкой плотности семян важны толщина ленты, тип клея и равномерность его нанесения. Карточки усиливаются рамками, вырезанными из картона толщиной $2-3 \mathrm{~mm}$.

Для реализации метода микрофокусной съемки семян специалистами Агрофизического научно-исследовательского института и Санкт-Петербургского государственного электротехнического университета „ЛЭТИ“ им. В.И. Ульянова (Ленина) был разработан совместно аппаратно-программный комплекс на осно- ве передвижной рентгенодиагностической установки ПРДУ-02 для контроля качества семян и зерна; организация-разработчик и предприятие-изготовитель: ЗАО „ЭЛТЕХ-Мед“, Санкт-Петербург, Россия [20]. В состав установки ПРДУ-02 (рис. 1,a) входят: рентгенозащитная камера для проведения рентгенографических работ; источник рентгеновского излучения моноблочного типа РАП70М-0,1H-1; приемник рентгеновского изображения на основе многофункционального портативного плоско-панельного детектора для цифровой рентгенографии; управляющая рабочая станция с универсальным программным обеспечением (рис. $1, b$ ) для анализа цифровых рентгеновских изображений семян. Коэффициент увеличения изображения составлял $3.0 \times$ для рентгеновской съемки.

Программная обработка цифровых изображений семян осуществлялась в программе ARGUS-BIO. Анализировались параметры „средняя яркость“, „минимальная 

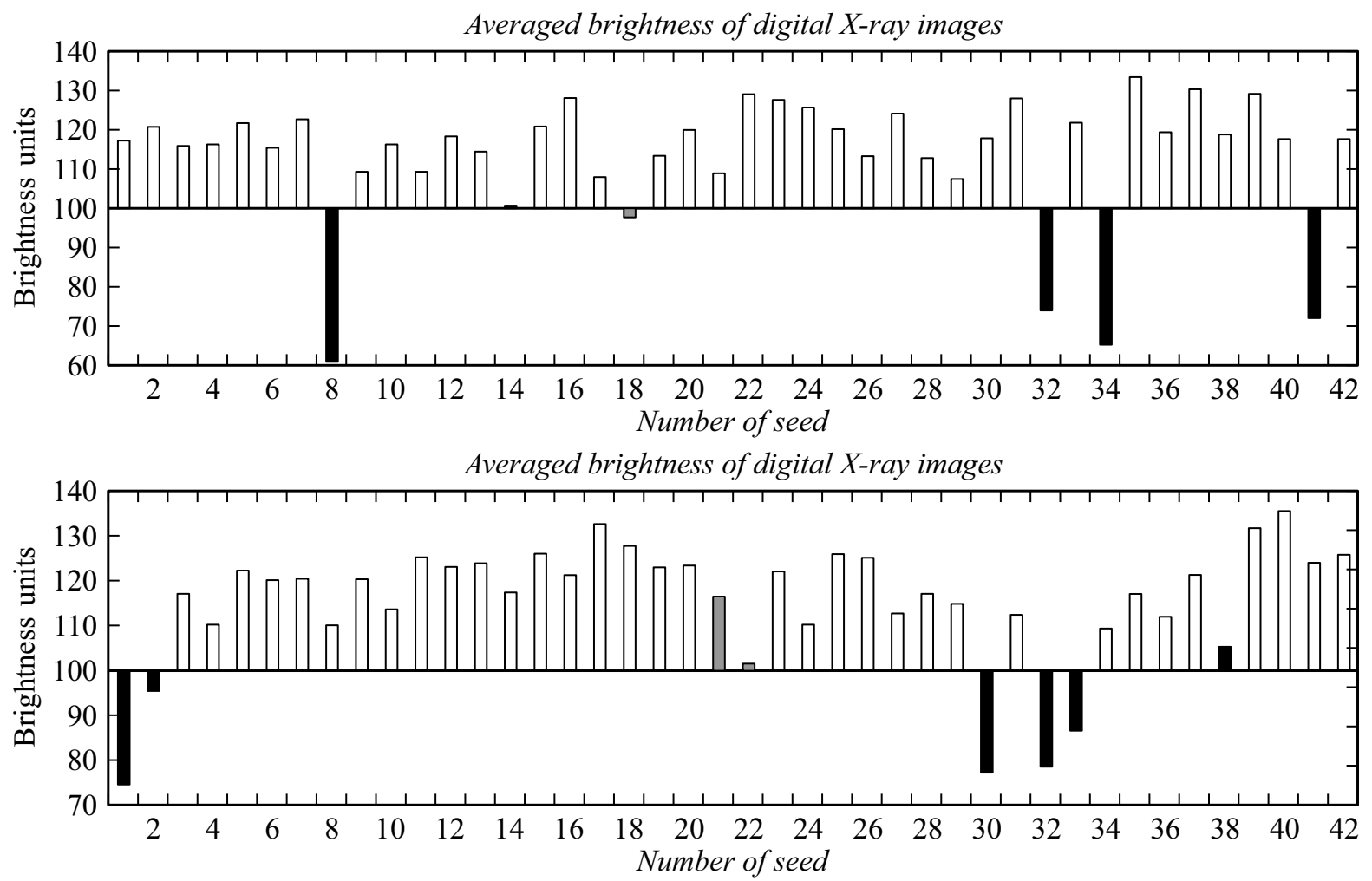

Averaged brightness of digital X-ray images

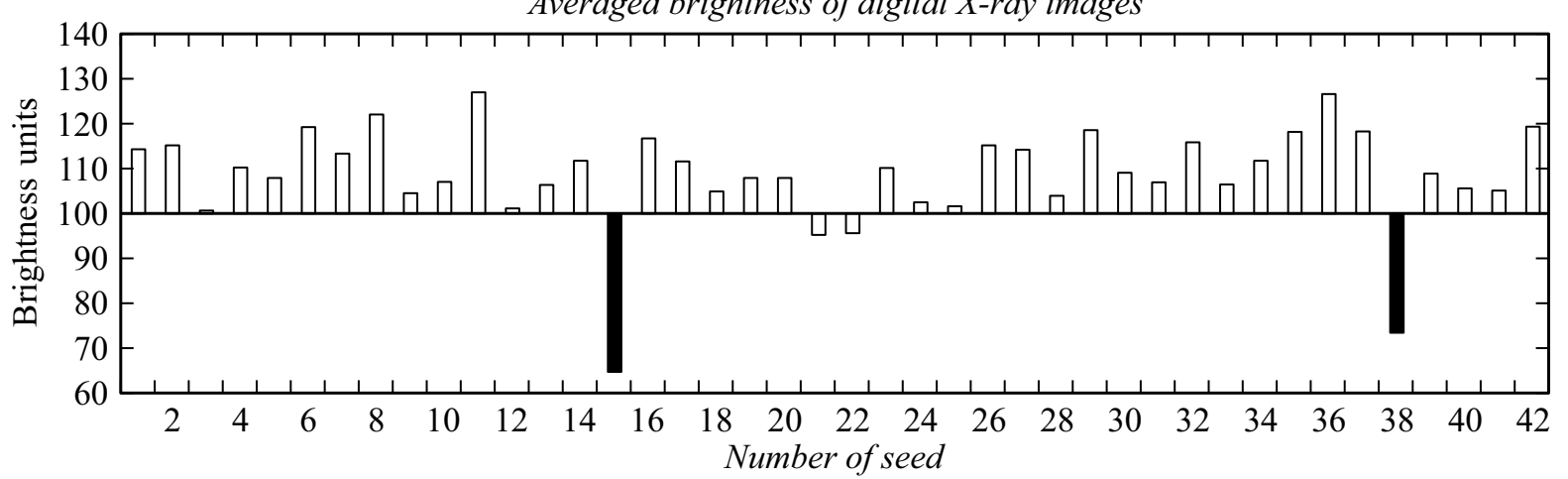

Рис. 3. Средняя яркость цифровых рентгеновских изображений семян сосны кедровой сибирской: $a-$ образец № $1, b-$ образец № 2 (происхождение Новосибирск), $c$ - образец происхождение Республика Тыва. Столбцы белого цвета (класс А) - нормальные (полнозернистые семена), серого (класс В) - частично пустозернистые, черного (класс С) - пустозернистые невыполненные семена.

яркость“, единицы яркости, яркостные разрезы [21], размерные и яркостные параметры отдельных структур и органов семени.

Масса индивидуальных семян оценивалась с использованием лабораторных весов ВЛТЭ-150 с точностью $0.001 \mathrm{~g}$.

Цифровые сканированные и рентгеновские изображения Pinus sibirica представлены на рис. 2, результаты исследований цифровых рентгеновских изображений сосны кедровой сибирской - на рис. 3).

Данные, представленные на рис. 3, показывают, что при пороговом значении средней яркости 100 единиц яркости возможно отделить пустозернистые и нормальные семена.
Результаты исследований веса индивидуальных семян сосны кедровой сибирской представлены на рис. 4.

Результаты сравнения эффективности методик микрофокусной рентгенографии в сочетании с анализом цифровых рентгеновских изображений и измерений веса индивидуальных семян по данным анализа семян сосны кедровой сибирской представлены в табл. 1.

Согласно нашим исследованиям, на выбранных образцах оба метода показали высокую эффективность (> 90\%) точности при выявлении невыполненных семян сосны кедровой сибирской и среднюю степень точности $(50 \%)$ - недовыполненных семян этого вида (табл. 1$)$.

На рис. 5 представлен пример дифференцированного анализа цифровых рентгеновских изображений семян 

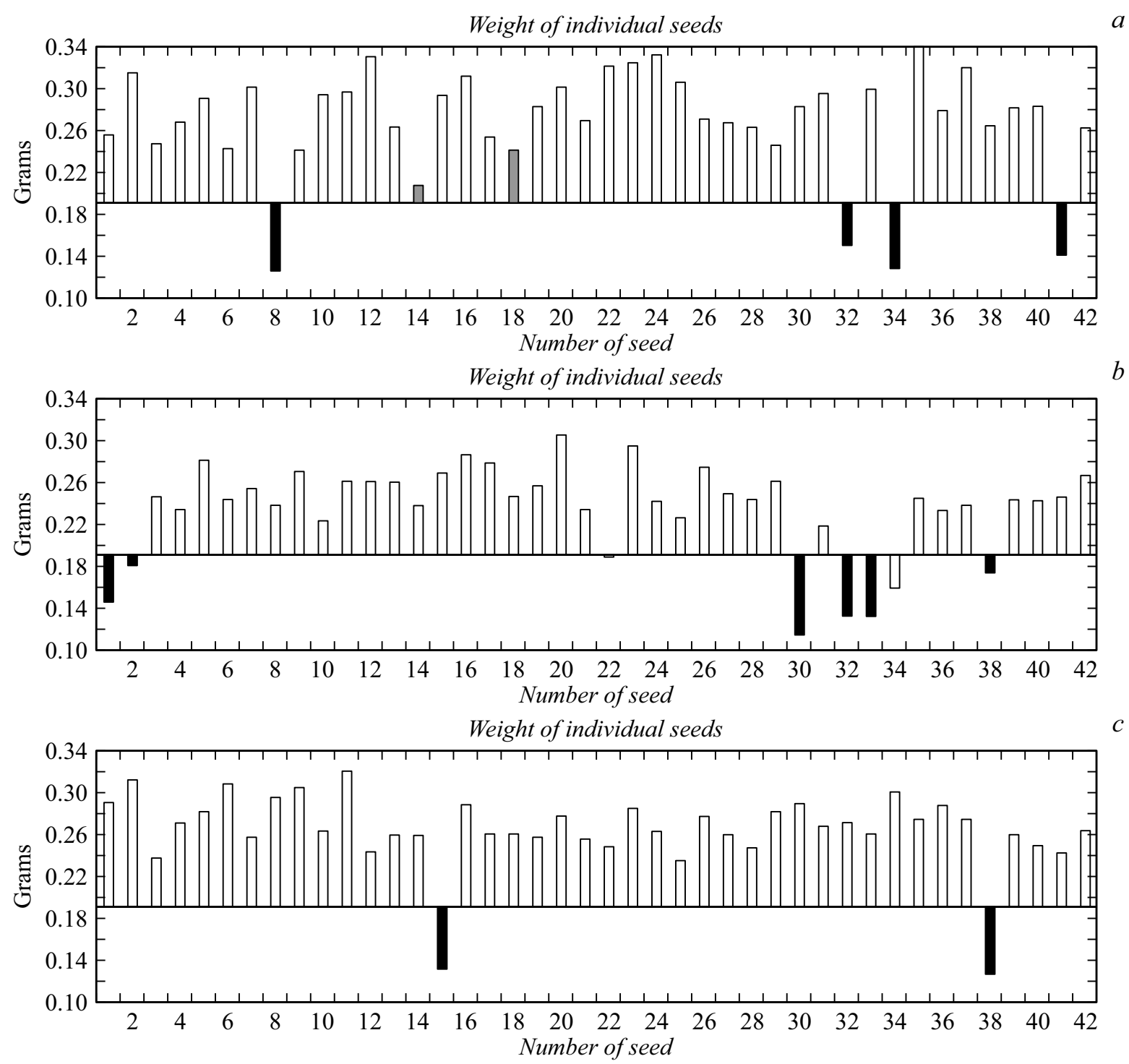

Рис. 4. Вес индивидуальных семян сосны кедровой сибирской: $a-$ образец № $1, b-$ образец № 2 (происхождение Новосибирск), $c$ - образец происхождение Республика Тыва. Столбцы белого цвета (класс А) - нормальные (полнозернистые семена), серого (класс В) - частично пустозернистые, черного (класс С) - пустозернистые невыполненные семена.

Таблица 1. Результаты сравнения эффективности методик микрофокусной рентгенографии в сочетании с анализом цифровых рентгеновских изображений и измерений веса индивидуальных семян

\begin{tabular}{c|c|c|c}
\hline \multirow{2}{*}{$\begin{array}{c}\text { Классы } \\
\text { объектов }\end{array}$} & \multirow{2}{*}{$\begin{array}{c}\text { Количество } \\
\text { объектов }\end{array}$} & Рентгенография + анализ изображений & Вес индивидуальных семян \\
\cline { 3 - 4 } & 110 & $98 / 2$ & $99 / 1$ \\
А & 4 & $50 / 50$ & $50 / 50$ \\
В & 12 & $92 / 8$ & $00 / 0$ \\
Всего объектов & 126 & - & -
\end{tabular}

сосны кедровой корейской: семя № 1, имеющее скрытые дефекты внутренней структуры, и семя № 2 - без скрытых дефектов. По нанесенным контурам в программе автоматически производятся геометрические и денситометрические измерения.
Основные характеристики, полученные по результатам дифференцированных измерений цифровых рентгеновских изображений семян, приведены в табл. 2.

Данные табл. 2 иллюстрируют разницу размерных и яркостных характеристик отдельных структур и орга- 


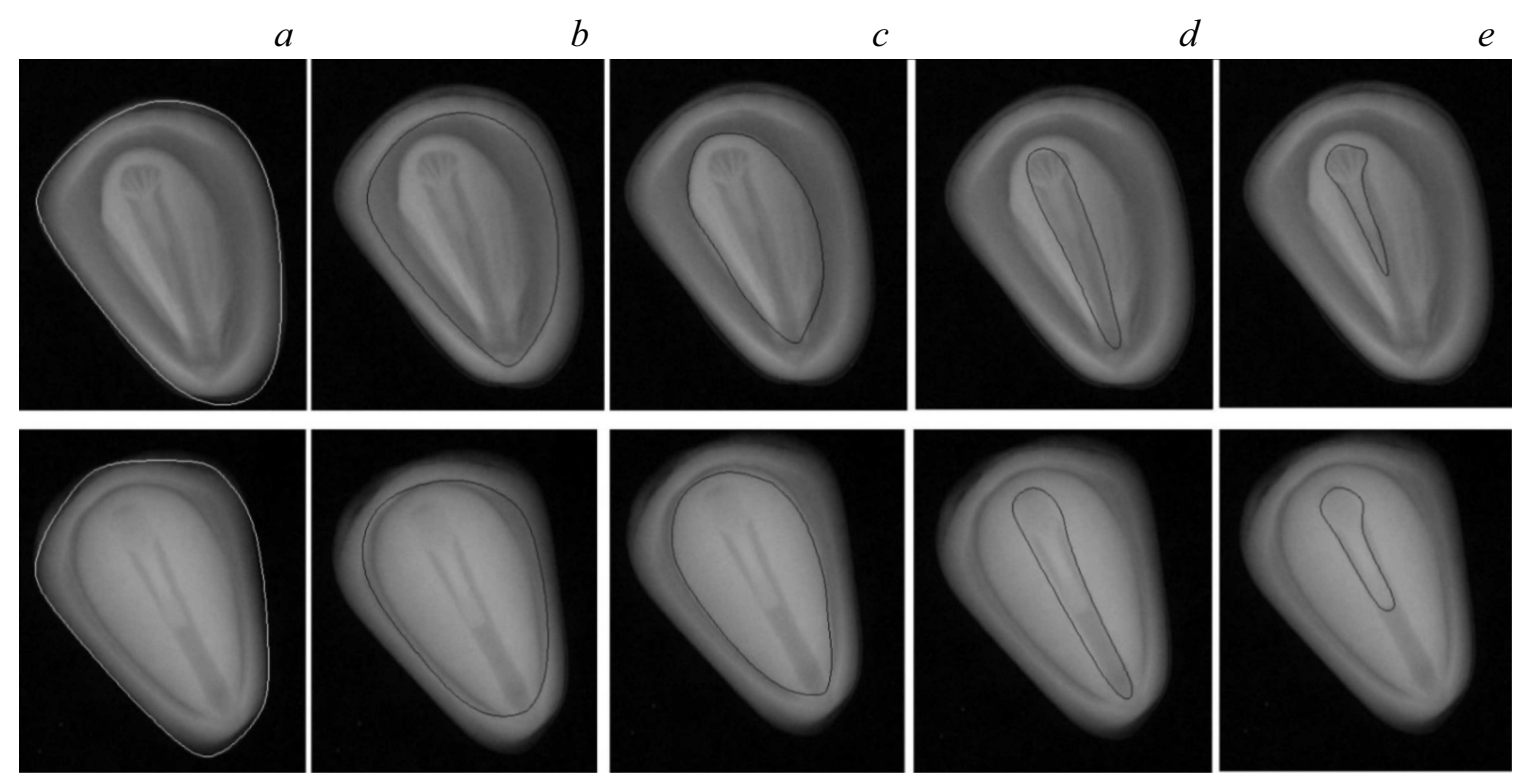

Рис. 5. Пример программной обработки цифровых рентгеновских изображений семян сосны кедровой, выполняемой путем интерактивного нанесения нескольких контуров, соответствующих отдельным структурам и органам семени: $a-$ внешний контур, соответствующий наружной оболочке (кожуре); $b-$ внутренний контур кожуры; $c$ - контур, соответствующий области эндосперма; $d-$ контур, соответствующий области ложа; $e-$ контур, соответствующий области зародыша. Верхний ряд - семя, имеющее дефектный зародыш и эндосперм; нижний ряд — семя без дефектов.
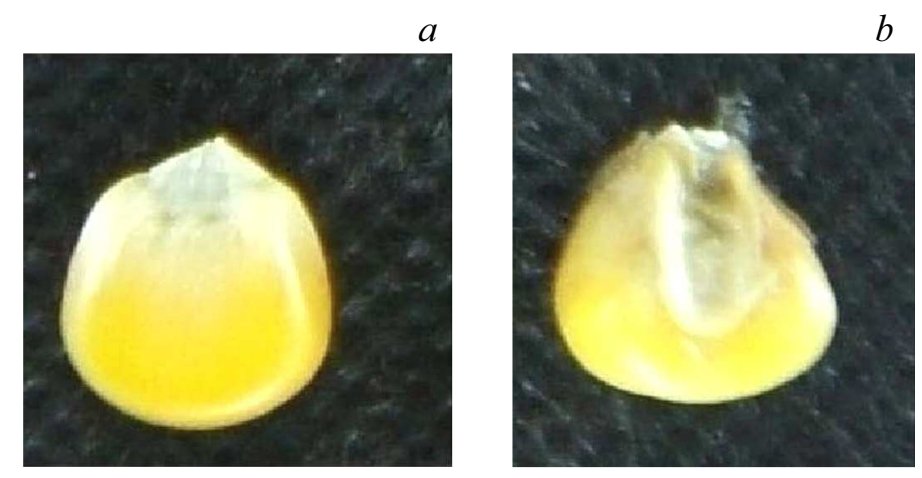

$b$

\section{$c$}
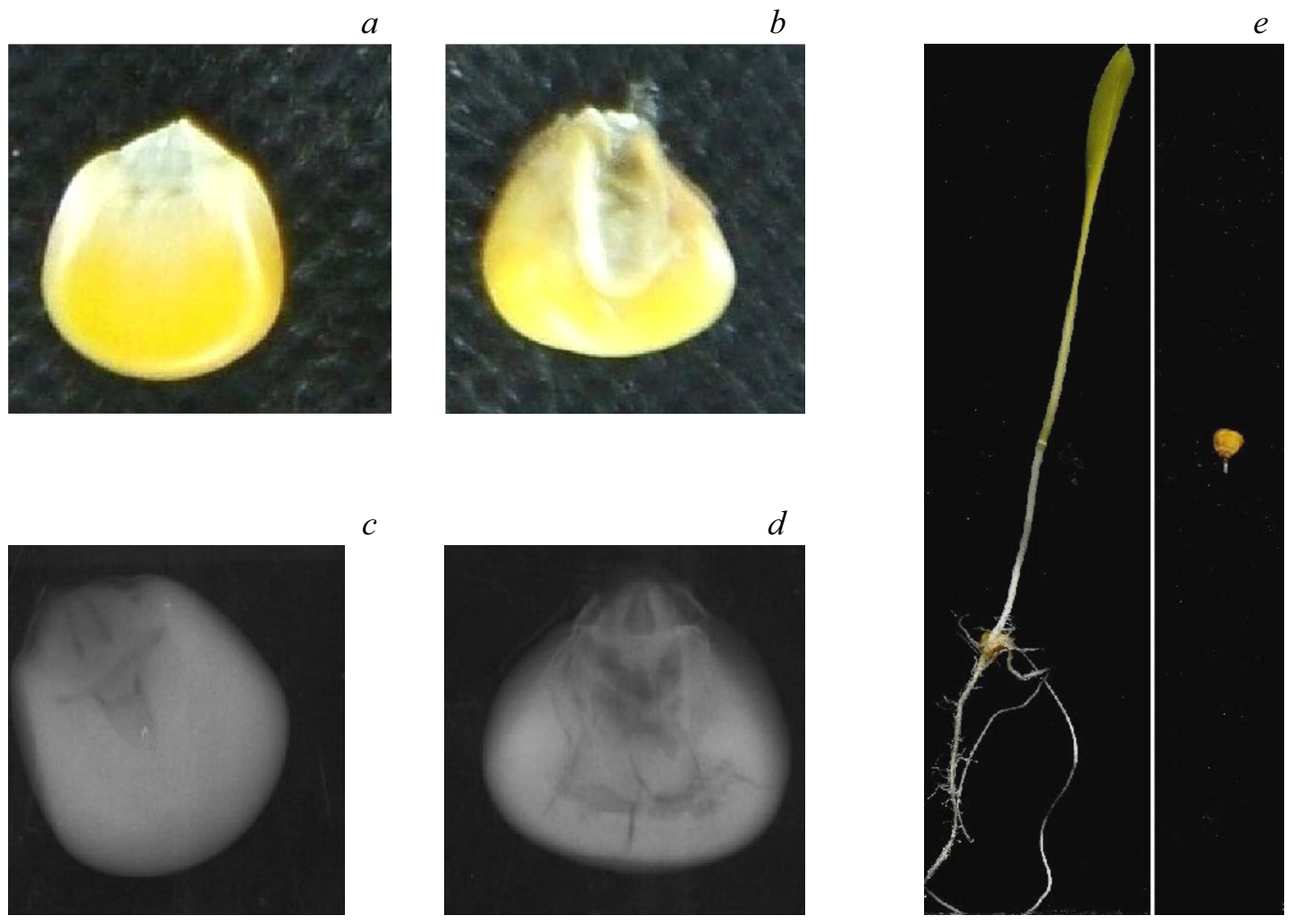

Рис. 6. Результаты рентгенографического анализа и сопряженного теста на проращивание семян кукурузы: цифровые сканированные изображения: $a-$ нормальное семя, $b-$ семя с дефектом биогенного происхождения (системное поражение инфекцией бактериальной этиологии), цифровые рентгеновские изображения: $c-$ нормальное семя, $d-$ семя с дефектом биогенного происхождения (системное поражение инфекцией бактериальной этиологии), $e$ - результат проращивания нормального и дефектного семени. 

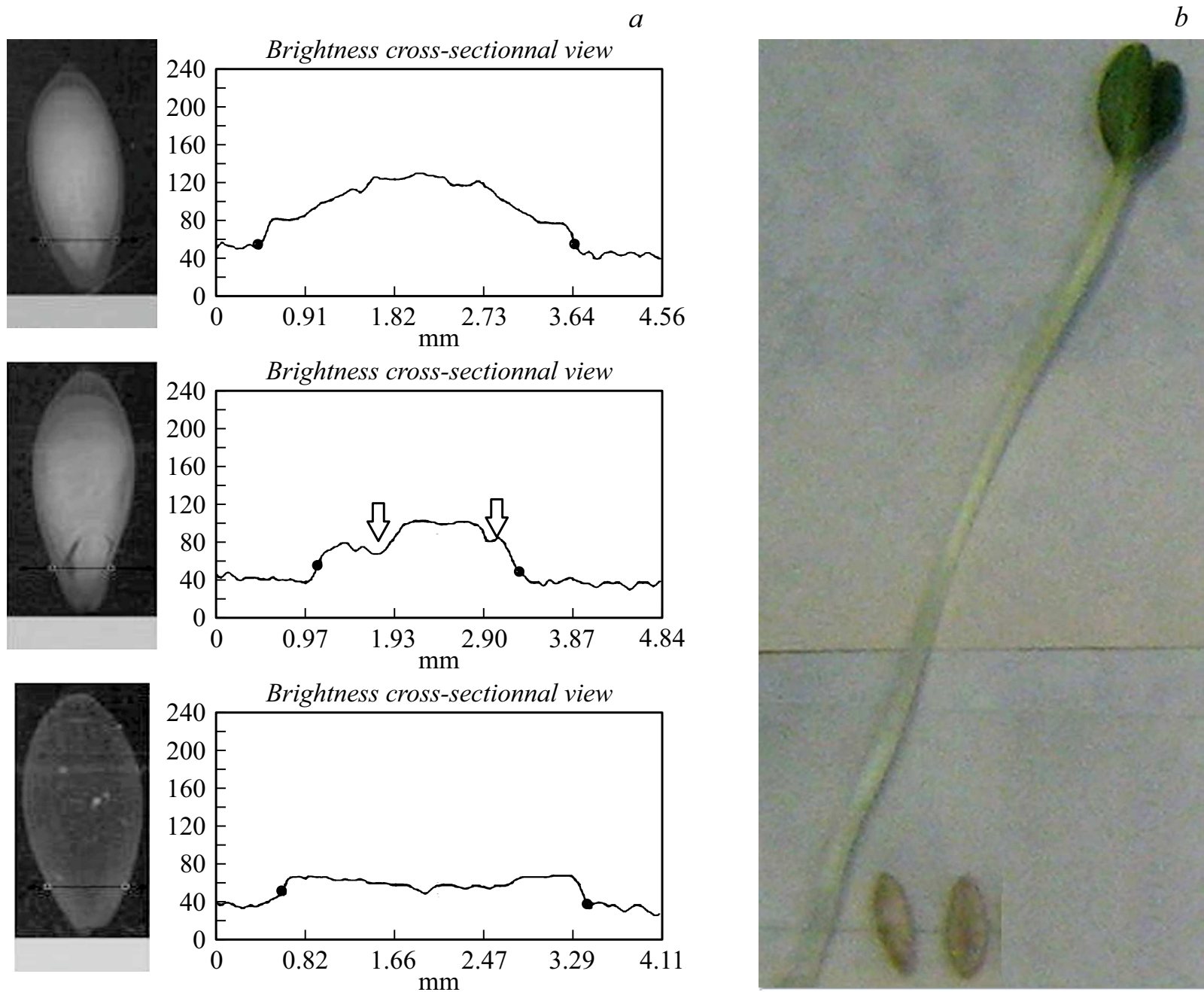

Рис. 7. Денситометрический анализ (яркостные разрезы) рентген-образов и результаты проращивания семян огурца: $a-$ вверху слева - норма; в середине слева - дефекты семядолей, внизу слева - невыполненность; $b$ - результаты теста на всхожесть.

$a$

$b$
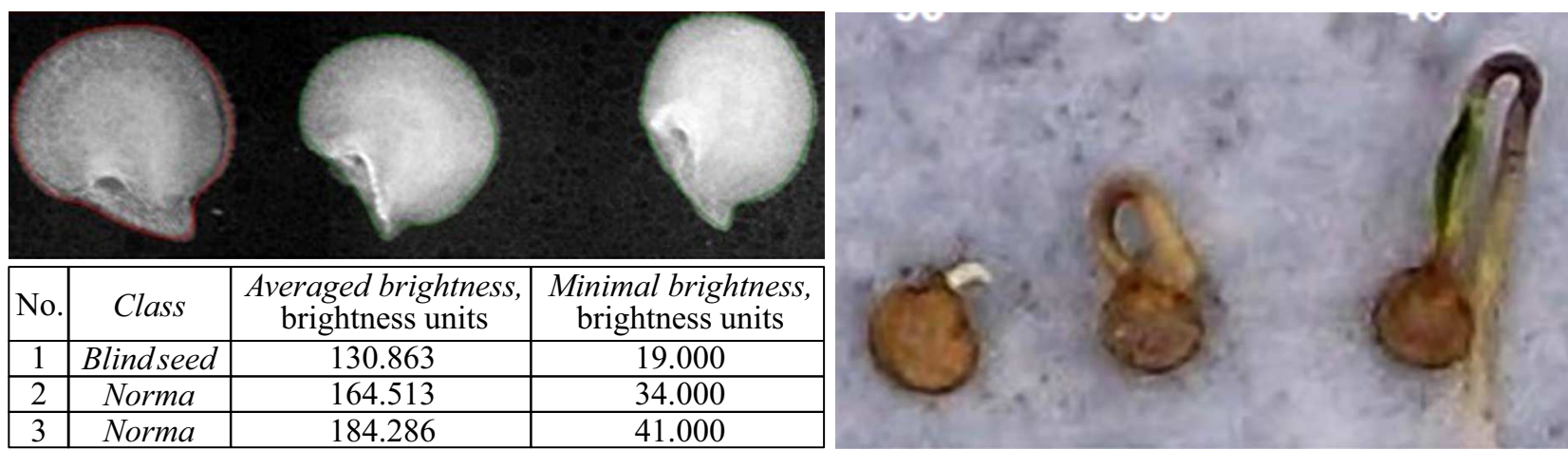

\begin{tabular}{|c|c|c|c|}
\hline No. & Class & $\begin{array}{c}\text { Averaged brightness, } \\
\text { brightness units }\end{array}$ & $\begin{array}{c}\text { Minimal brightness, } \\
\text { brightness units }\end{array}$ \\
\hline 1 & Blindseed & 130.863 & 19.000 \\
\hline 2 & Norma & 164.513 & 34.000 \\
\hline 3 & Norma & 184.286 & 41.000 \\
\hline
\end{tabular}

Рис. 8. Пример денситометрического анализа $(a)$ (яркостные параметры) рентген-образов семян перца: невыполненность, близкая к норме, норма и результаты проращивания $(b)$ семян перца - невыполненность, близкая к норме, норма.

нов семени. Аномалии развития зародыша могут быть объективированы через следующие характеристики: площадь проекции зародыша, $\mathrm{mm}^{2}$ (снижена), отношение площадей проекции зародыша и проекции ложа, \% (снижена), относительная площадь проекции зародыша, \% (снижена), фактор эллипса области проекции зародыша, относительные единицы (снижен), по сравнению с семенем с нормально развитым зародышем. 
Таблица 2. Количественные характеристики отдельных структур и органов семян, полученные путем дифференцированного анализа цифровых рентгеновских изображений

\begin{tabular}{c|l|r|r}
\hline \multirow{2}{*}{$\begin{array}{c}\text { № } \\
\text { п.п. }\end{array}$} & \multicolumn{1}{|c}{ Показатель, единицы измерения } & \multicolumn{2}{|c}{ Значения показателей } \\
\cline { 3 - 4 } & & Семя № 1 & Семя № 2 \\
\hline 1 & Площадь проекции зародыша, $\mathrm{mm}^{2}$ & 10.61 & 13.07 \\
2 & Средняя яркость проекции зародыша, единицы яркости & 118.46 & 143.13 \\
3 & Отношение площадей проекции зародыша и проекции ложа, \% & 42.66 & 48.52 \\
4 & Относительная площадь проекции зародыша, \% & 5.32 & 7.00 \\
5 & Фактор эллипса области проекции зародыша, отн. ед. & 0.865 & 0.929 \\
6 & Площадь проекции эндосперма, то ${ }^{2}$ & 44.31 & 65.20 \\
7 & Относительная площадь области эндосперма, \% & 34.67 & 49.37 \\
8 & Относительная площадь области отслоения оболочки, \% & 28.27 & 15.62
\end{tabular}

Результаты рентгенографического анализа и сопряженного теста на проращивание семян кукурузы представлены на рис. 6.

Согласно изображениям, представленным на рис. 6, дефектное семя характеризуется более темной рентгенпроекцией по сравнению с нормальным семенем. При проращивании последнее в отличие от первого дало нормальный проросток.

Невыполненность семени огурца посевного показывает, что средняя яркость рентгенограмм понижена (54.853 единиц яркости) по сравнению нормальным семенем (113.578 единиц яркости). Семя с дефектом семядолей характеризуется промежуточным значением показателя средней яркости (99.989 единиц яркости) (рис. 7).

Яркостные разрезы демонстрируют степень неоднородности рентген-проекции семени огурца. Максимальная вариабельность кривой средней яркости просматривается на семени с дефектом семядолей (рис. 7,a). Рис. 7, $b$ показывает, что проращивание семян подтверждает рентгенографический анализ. Семя с нормальным строением проросло, дефектные - нет.

Таким образом, яркостные параметры рентгеновских изображений позволяют характеризовать степень дефектности семян огурца.

Невыполненность семени перца овощного показывает, что средняя яркость рентгенограмм понижена (130.863 единиц яркости) по сравнению с нормальным семенем (184.286 единиц яркости), а также семенем по рентгенографическим характеристикам, близким к норме (средняя яркость 164.513 единиц яркости) (рис. 8, a). Максимальные ростовые показатели наблюдаются у семени с нормальным анатомическим строением, семя с пониженными значениями показателя „средняя яркость“ характеризуется минимальным ростовым потенциалом (рис. $8, b$ ).

Таким образом, средняя яркость позволяет характеризовать степень дефектности семян перца.

На рентгеновском изображении (проекции) нормального семени присутствуют затемнения регулярного, ожидаемого характера. Такие затемнения, как и темные линии границ деталей зародыша, называемые регуляр- ными, непременно присутствуют на проекциях нормального семени. Нерегулярные затемнения, например, наблюдаемые в каком-либо месте того же корешка, говорят о локальной потере плотности этого органа, т.е. о его поврежденности, не позволяющей относить данное семя к полноценному, нормальному [2]. Классическими примерами нерегулярных затемнений могут служить дефекты биогенного происхождения, в частности, энзимомикозное истощение [22], поврежденность насекомыми [23] и дефекты, связанные с аномалиями развития семени (невыполненность) [2].

Проблема сопоставления рентгеновских и морфофизиологических характеристик проростков является сложной по ряду причин как технического, так и биологического свойства, а именно:

- цифровые рентгеновские изображения семян были получены только в одной (единственной) проекции. При изменении положения семени при рентген-съемке визуализация и соответственно количественная оценка дефекта может быть отличной от первоначальной [24];

- биологически полноценные семена также гетерогенны по показателям энергии прорастания, всхожести и силы роста, отражающим потенциальную продуктивность [25]. Причина такого разнообразия может быть связана, в частности, с различиями в морфологических признаках зародыша, которые могут быть идентифицированы как рентген-позитивные признаки [26].

В этом случае необходим количественный анализ цифровых рентгеновских изображений, с использованием методов классификации снимков [27,23].

\section{Заключение}

Представлена методика микрофокусной рентгенографии и приемы автоматического анализа цифровых рентгеновских изображений для выявления скрытой дефектности семян древесных лесных пород и других видов растений. 
Приведены характеристики современных аппаратных решений, используемых для получения цифровых рентгеновских изображений семян.

Описаны основные способы визуализации и приемы анализа цифровых рентгеновских изображений семян. Выявлены и проанализированы скрытые дефекты образцов семян исследуемых древесных лесных пород, кукурузы сахарной, огурца посевного и перца овощного методом микрофокусной рентгенографии в сочетании с автоматическим анализом цифровых рентгеновских изображений. Показано, что пустозернистые и частично полнозернистые семена имеют пониженные значения показателя „средняя яркость“ рентгенограмм.

Проведена сравнительная оценка рентгеновских показателей и всхожести проростков как интегральных показателей для оценки биологической полноценности семян.

Представленные данные позволяют сделать заключение о том, что метод микрофокусной рентгенографии в сочетании с автоматическим анализом цифровых рентгеновских изображений может являться эффективным дополнительным инструментом для оперативного выявления дефектных семян древесных лесных пород и других видов растений и стать основой для создания промышленных сортировщиков (сепараторов) семян для нужд сельского и лесного семеноводства.

\section{Конфликт интересов}

Авторы заявляют, что у них нет конфликта интересов.

\section{Список литературы}

[1] Архипов М.В., Потрахов Н.Н. Микрофокусная рентгенография растений. СПб.: Технолит, 2008. 192 с.

[2] Мусаев Ф.Б., Потрахов Н.Н., Архипов М.В. Рентгенография семян овощных культур. СПб.: ЛЭТИ, 2016. 206 с.

[3] Burg W.J., van der Jalink H., Zwol R.A., van Aartse J.W., Bino R.J. // Acta Horticulturae. 1995. Vol. 362. P. 149-157.

[4] Moreira M.L. de, Aelst A.C. van, Eck J.W. van, Hoekstra F.A. // Seed Science Research. 1999. Vol. 9. P. 227-236.

[5] Gomes-Junior F.G., Yagushi J.T., Belini U.L., Cicero S.M., Tomazello-Filho M. // Seed Sci. Technol. 2012. Vol. 40. N 1. P. 102-107.

[6] Silva V.N., Cicero S.M., Bennett M. // Seed Sci. Technol. 2013. Vol. 41. N 2. P. 225-234.

[7] Simak M., Gustafsson A. // Heraditas. 1953. N 3. P. 458-468.

[8] Kamra S.K. // Studia Forestalia Suecica. 1976. N 131. P. 1-34.

[9] Sandeep Varma V., Kanaka Durga K., Keshavulu K. // A Rev. Intern. Res. J. Agricultural Sci. 2013. Vol. 1. N 2. P. 30-36.

[10] Kapadia V.N., Sasidharan N., Patil K. // Adv. Biotechnol. Microbiol. 2017. Vol. 7. N 2. P. 1-3. DOI: org/10.19080/AIBM.2017.07.555709.017

[11] Мусаев Ф.Б. Научно-практические аспекты совершенствования контроля качества семян овощных культур. Автореф. канд. дис. М. 2018. 50 с.
[12] Sahlen K., Bergsten U., Wiklund K. // Seed Sci. Technol. 1995. Vol. 23. P. 405-414.

[13] ГОСТ 12038-84. Семена сельскохозяйственных культур. Методы определения всхожести.

[14] Zappala S., Helliwell J.R., Tracy S.R., Mairhofer S., Sturrock C.J., Pridmore T., Bennett M., Mooney S.J. // PLOS ONE. 2013. Vol. 8. N 6. P. 1-8.

DOI: org/10.1371/journal.pone.0067250

[15] Al Turki T.A., Baskin C.C. // Saudi J. Biolog. Sci. 2017. Vol. 24. P. $822-829$.

[16] Архипов М.В., Алексеева Д.И., Батыгин Н.Ф., Великанов Л.П., Гусакова Л.П., Дерунов И.В., Желудков А.Г., Николенко В.Ф., Никитина Л.И., Савин В.Н., Пономаренко Е.Н., Якушев В.П. Методика рентгенографии в земледелии и растениеводстве / Под ред. М.В. Архипова. M. 2001. 94 c.

[17] Архипов М.В., Прияткин Н.С., Гусакова Л.П., Потрахов Н.Н., Дмитриев С.В. // Агрофизика. 2018. № 3. С. 38 42. DOI: $10.25695 /$ AGRPH.2018/03/07

[18] Прияткин Н.С., Кузнецова Т.А., Кузнещова М.А., Гусакова Л.П., Пищик В.Н. Исследование интроскопических характеристик и ростовых показателей образцов зерен кукурузы с использованием инструментальных физических и стандартных методов для оценки их посевных качества и степени фитосанитарных рисков. Неделя науки СПбПУ: материалы научн. конф. с международ. участием. Высшая школа биотехнологий и пищевых технологий. СПб.: Издво Политех. ун-та, 2017. С. 128-131.

[19] Прияткин Н.С., Архипов М.В., Гусакова Л.П., Шабунин Д.С., Бутенко О.Ю., Бойцов А.А., Потрахов Н.Н., Староверов Н.Е., Саввина К.А. // Тр. СанктПетербургского НИИ Лесного хозяйства. 2018. № 2. С. 4 17. DOI: $10.21178 / 2079-6080.2018 .1 .4$

[20] Архипов М.В., Демьянчук А.М., Великанов Л.П., Потрахов Н.Н., Грязнов А.Ю., Потрахов Е.Н. Устройство для рентгенодиагностических исследований зерна и семян. Пат. РФ № 85292, МПК А01С 1/02. Заявлено Бюл. № 22. 10.08.2009.

[21] Пантелеев В.Г., Егорова О.В., Клыкова Е.И. Компьютерная микроскопия. М.: Техносфера, 2005. 303 с.

[22] Темирбекова С.К. О проблеме энзимо-микозного истощения семян („истекании“ зерна) в растениеводстве. М.: Россельхозакадемия, 1998. $306 \mathrm{c}$.

[23] Прияткин Н.С., Архипов М.В., Гусакова Л.П., Бойцов А.А., Потрахов Н.Н., Староверов Н.Е., Щукина П.А., Капусткина А.В. // Изв. СПб ГЭТУ ЛЭТИ. 2018. № 6. C. 60-67.

[24] Grundas S., Velikanov L., Archipov M. // Int. Agrophysics. 1999. Vol. 13. P. 355-361.

[25] Савин В.Н., Архипов М.В., Баденко А.Л., Иофббе Ю.К., Грун Л.Б. // Вестник сельскохоз. науки. 1981. № 10. C. 99-104.

[26] Дерунов И.В. Рентгенографическое исследование семян различных сельскохозяйственных культур и продуктов их переработки. Автореф. канд. дис. СПб. 2004. 22 с.

[27] Narvankara D.S., Singha C.B., Jayasa D.S., White N.D.G. // Biosystems Engineering. 2009. Vol. 103. P. 49-56. 